\author{
О.І. Тимочко ${ }^{1}$, В.В. Афанасьєв ${ }^{1}$, Ю.В. Афанасьєв ${ }^{2}$, О.О. Аросланкін ${ }^{1}$ \\ ${ }^{1}$ Харківський начіональний університет Повітряних Сил ім. І. Кожедуба, Харків \\ ${ }^{2}$ Харківський національний університет радіоелектроніки, Харків
}

\title{
МОДЕЛЬ СИСТЕМИ ПОЗИЦІОНУВАННЯ ТА МОНТТОРИНГУ НА ОСНОВІ БАГАТОРІВНЕВОЇ СТРУКТУРИ ПЕРЕДАЧІ ДАНИХ В РОЗПОДІЛЕНІЙ МЕРЕЖІ
}

\begin{abstract}
В роботі запропонована модель системи позиціонування та моніторингу на основі багаторівневої структури передачі даних в розподіленій мережі. Обтрунтування моделі виконано на основі дослідження технологій обміну даними, апаратних компонентів, програмного забезпечення, варіантів топології побудови систем обміну даними. Проведено експериментальне дослідження реалізації функцій моніторингу та позиціонування на основі застосування моделі, щзо запропонована. Показано, щяо до основних властивостей моделі відноситься масштабування структури в залежності від конкретних задач, можливість поєднання в єдину систему стаціонарних та рухомих елементів, які здійснюють збір, обробку та передачу даних. Область застосування моделі, щзо запропонована, ие віддалені райони, де відсутній стільниковий зв'язок, роззосереджені промислові об'єкти, аеродроми. Дана модель може бути основою для удосконалення систем пошуково-рятувального забезпечення та системи управління повітряним рухом при застосуванні безпілотних літальних апаратів, в тому числі спільно з пілотованою авіацією.
\end{abstract}

Ключові слова: безпілотні літальні апарати, модель, моніторинг, система навігації, позиціонування, LoRa, Wi-Fi.

\section{Вступ}

Постановка проблеми. Розвиток безпілотної авіації обумовлює необхідність дослідження питань щодо забезпечення безпеки польотів, особливо при спільному використанні повітряного простору з пілотованою авіацією. На даний час ці питання вирішуються за рахунок виконання організаційних заходів 3 питань дотримання вимог керівних документів з безпеки польотів (ICAO) та $з$ використанням існуючих технічних систем контролю повітряного простору, які застосовуються в задачах контролю, навігації, спостереження та організації повітряного руху (CNS/ATM) для пілотованої авіації [1-2]. Вирішення задачі по інтеграції пілотованої та безпілотної авіації в єдиний повітряний простір можливе за рахунок розробки спеціалізованих систем, що підтверджується напрямками досліджень, які направлені на забезпечення обміну даними безпосередньо між літальними апаратами та з органами управління повітряним рухом [3]. Такі системи мають розподілену структуру. За результатами постійного спостереження за повітряною обстановкою та отриманими просторовими даними літальних апаратів реалізуються алгоритми управління відповідно до ситуативних варіантів. Для забезпечення безпечної організації спільного використання повітряного простору необхідна інформація про просторове положення літальних апаратів, їх маршрути руху, програмно-апаратне забезпечення для розв'язання задач в системі CNS/ATM та ін. Ці складові $є$ елементами систем інформаційного забезпе- чення, які на даний час існують та розробляються окремо для пілотованої та безпілотної авіації. Одними з основних рис цих систем є реалізація взаємодії між їх елементами без участі людини, тобто організації міжмашинної взаємодії (М2М); використання сучасних географічних інформаційних систем (ГІС). Ці системи забезпечують отримання, обробку та аналіз даних $з$ прив'язкою у просторі та часі [4-5].

Ефективне та безпечне виконання завдань авіацією залежить не тільки від якості організації управління повітряним рухом, а також від організації контролю за рухом наземних засобів, контролю стану функціонування наземних засобів забезпечення польотів, наприклад систем навігації і посадки, моніторингу метеорологічної та орнітологічної обстановки та ін. Аналіз стану та розвитку сучасних телекомунікаційних технологій показує, що одним 3 перспективних напрямків $є$ застосування різних технологій бездротової передачі даних, апаратних елементів 3 малим рівнем енергоживлення, програмних засобів з елементами штучного інтелекту та ін. [6-7].

Аналіз останніх досліджень і публікацій. Аналіз структури складних технічних об'єктів показує, що вони являють собою систему елементів, які об'єднані в зосереджені та роззосереджені структури 3 мережевою архітектурою. Обмін інформацією між елементами системи здійснюється на основі використання різноманітних комунікаційних технологій. Вибір технологій визначається вимогами до каналів обміну даними. 
В роботі [8] розглянуто доцільні форми бойового застосування та способи бойових дій при спільному виконанні завдань пілотованою та безпілотною авіацією. Це обумовлює підвищення інтенсивності використання повітряного простору, як на окремих ділянках в районах виконання завдань, так i в районах аеродромів. Запропоновано напрямок досліджень щодо удосконалення існуючої системи управління авіацією шляхом створення єдиного інформаційного простору на основі інтеграції систем управління пілотованої та безпілотної авіації. Визначено зміст складових, однією з рис яких є застосування стандартних протоколів повідомлень, функції збору, обробки інформації та ін. До обмежень функціонування системи, що запропонована, можна віднести відсутність взаємодії з питань обміну інформацією $з$ пунктами управління інших видів Збройних Сил та інших військових формувань. Поєднання всіх джерел інформації в єдиний інформаційний простір можливо шляхом реалізації концепції C4ISR [9]. Особливості методів виявлення, розпізнавання та вимірювання координат безпілотних літальних апаратів викладено в роботі [10]. Показано, що до основних методів відносяться акустичний, інфрачервоний, оптичний та радіолокаційний [11-12]. Найбільш універсальним залишається радіолокаційний метод, але він має обмеження по виявленню цілей, які виконують польоти на малих та гранично малих висотах, де утворюються потужні пасивні завади у вигляді віддзеркалень від місцевих предметів (рельєфу місцевості, штучних перешкод). Частково задачі по виявленню безпілотних літальних апаратів (БПЛА) можуть бути вирішені при застосуванні радіолокаційних висотомірів, але це неможливо виконувати при вирішенні основних завдань.

Таким чином, одним 3 шляхів підвищення ефективності контролю за повітряним простором $€$ комплексне застосування методів виявлення повітряних об'єктів. Система однотипних засобів моніторингу буде мати розподілену топологію у просторі, що потребує об'єднання всіх засобів в єдину мережу з використанням різних бездротових технологій. Для обміну даними на малих відстанях застосовуються технології групи стандартів IEEE 802, UWB (Ultra-Wide Band). Обмін даними між розосередженими елементами інформаційної системи можливий при застосуванні технології, які забезпечують передачу даних на великі відстані, наприклад технологія LoRa (Long Range) забезпечує передачу даних на великі відстані з низьким енергоживленням [13-15]. Задачі координатно-часової прив'язки вирішуються за рахунок використання супутникових радіонавігаційних систем (GNSS).

Мета статті - $€$ забезпечення позиціонування та моніторингу обстановки на основі комплексного застосування різних бездротових технологій обміну даними.

\section{Виклад основного матеріалу}

Для досягнення цілі, що поставлена в роботі, необхідно провести дослідження окремих напрямків, а саме: технологій обміну даними, апаратних компонентів, програмного забезпечення, варіантів топології побудови систем обміну даними. Названі елементи та зв'язок між ними представляють собою структуру комплексної моделі системи позиціонування та моніторингу (рис. 1).

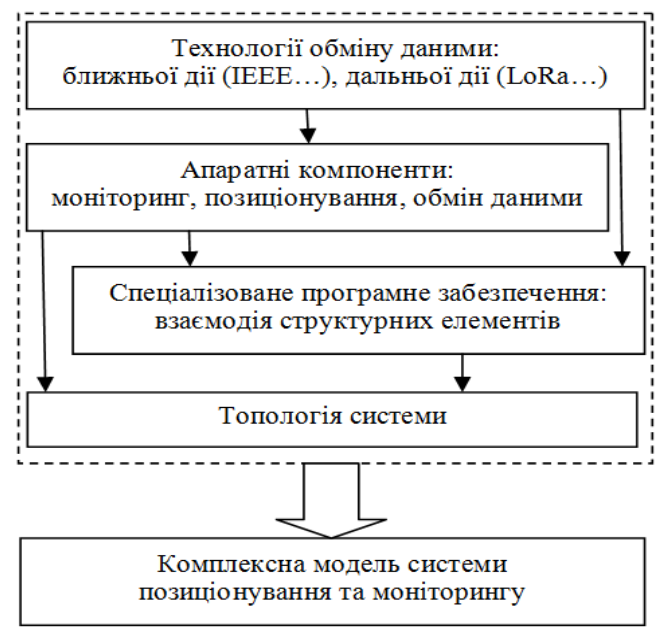

Рис. 1. Структура комплексної моделі системи позиціонування та моніторингу Джерело: розроблено авторами.

Розробка моделі базується на принципі побудови функціонально стійких комунікаційних мереж [16-18].

В якості системи передачі даних моніторингу можливо розглядати існуючу систему стільникового зв'язку. Аналіз покриття цих систем показує, що вони не забезпечують створення суцільного поля зв'язку. Причому, зони покриття стандартами зв'язку також відрізняються (рис. 2).

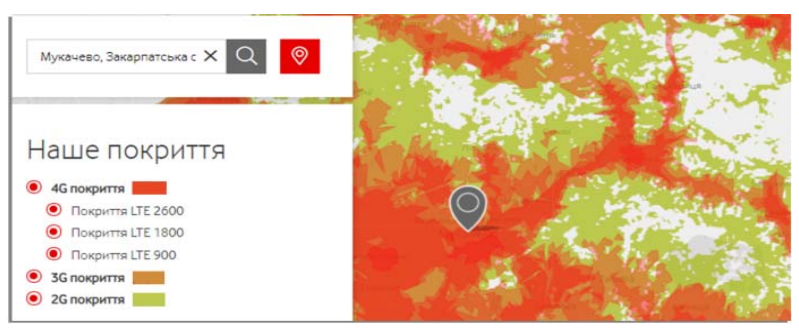

Рис. 2. Карта покриття Vodafone

Джерело: розроблено авторами за даними [19].

Наявність районів, де відсутнє покриття, необхідно розглядати інші варіанти для оперативного розгортання системи моніторингу. Ці райони характеризуються віддаленістю від населених пунктів, транспортних мереж, складними фізикогеографічними умовами. Всі ці фактори обумовлюють вибір технологій бездротової передачі даних та 
3 низьким рівнем енерговитрат. Запропоновано розглянути в комплексі застосування технології малої та великої дальності дії для зосереджених та розосереджених об'єктів. Варіантами для дослідження обрано технології Wi-Fi та LoRa. Реалізація систем моніторингу та позиціонування та обміну даними потребує великої кількості електронних компонентів, які забезпечують функціонування системи. Для уніфікації таких систем необхідно обирати компоненти, які можуть бути використані в різноманітних структурах системи, що дозволить поєднувати окремі системи в єдиний інформаційний комплекс.

До основних властивостей, які необхідно враховувати при виборі апаратних компонентів відносяться: можливість використання сенсорів, принцип роботи яких заснований на різних методах визначення фізичних параметрів, що дозволить здійснювати моніторинг навколишнього середовища, визначення параметрів руху повітряних та наземних об'єктів та ін.; забезпечення функціонування вузлів мережі системи моніторингу в якості шлюзу для передачі даних споживачам; енергоефективність, що дозволить забезпечувати автономність виконання задач у віддалених районах; низька вартість, що має суттєвий вплив на реалізацію системи при великій кількості сенсорів. Рішення задачі позиціонування, тобто визначення координатно-часової інформації необхідно здійснювати як традиційними методами на основі даних GNSS, так і на основі інших мето- дів, які можливо реалізувати на основі інформації, що отримується в системі. Оскільки розглядаються питання комплексного застосування різноманітних комунікаційних технологій, необхідно виділити можливі варіанти взаємодії функціональних елементів системи. Враховуючи вимогу універсальності до апаратного забезпечення системи, така ж вимога стосується і програмного компонента. Такий підхід дозволяє реалізувати його в різних проектах на однотипній елементній основі. Визначення вимог до програмного компонента базується на задачі забезпечення функціонування елементів системи позиціонування та моніторингу на основі багаторівневої структури взаємодії технологій безпровідної передачі даних [20]. Універсальність - властивість контролерів, яка забезпечує їх застосування в різних проектах. Функціонування програмного забезпечення буде визначатись характером вхідної та вихідної інформації на контролері. Таким чином, контролер, як ланка системи, котрий має модуль передачі даних, може виконувати функцію не тільки як ретранслятор даних, а й як перетворювач. Так як розглядається два типи технологій передачі даних: ближньої дії, дальньої дії, то приймемо наступні позначення БД та ДД відповідно. Для розробки моделі системи визначено перелік структурних елементів, їх умовні позначення та функціональні зв'язки на апаратному та програмному рівнях (табл. 1).

Таблиця 1

Елементи системи, позначення, функціональна взаємодія

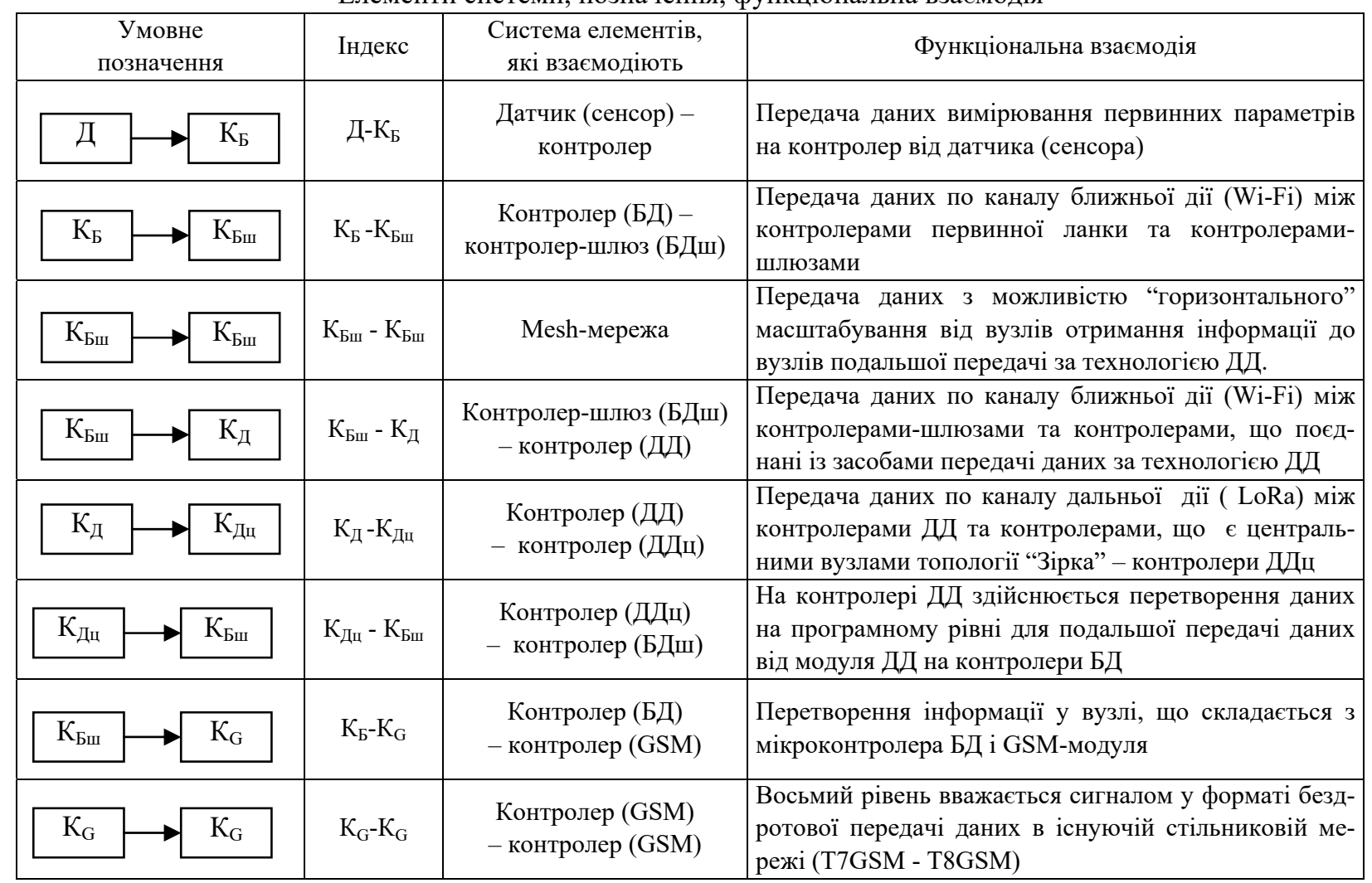

Джерело: розроблено авторами. 
Особливостями застосування технології LoRa $\epsilon$ обмеження в реалізації тільки топології “зірка”, але кожний вузол окремої “зірки” може бути елементами іншої структури - “зірки”, що дозволяе організовувати мережі зі складною топологією на великих ділянках місцевості.

Таким чином, датчики (сенсори), контролери, технології та засоби безпровідної передачі даних, варіанти топології поєднання вузлів в єдину мережу $\epsilon$ складовими моделі системи позиціонування та моніторингу на основі багаторівневої структури їх взаємодії. рис. 3 .

Варіант реалізації даної моделі представлено на

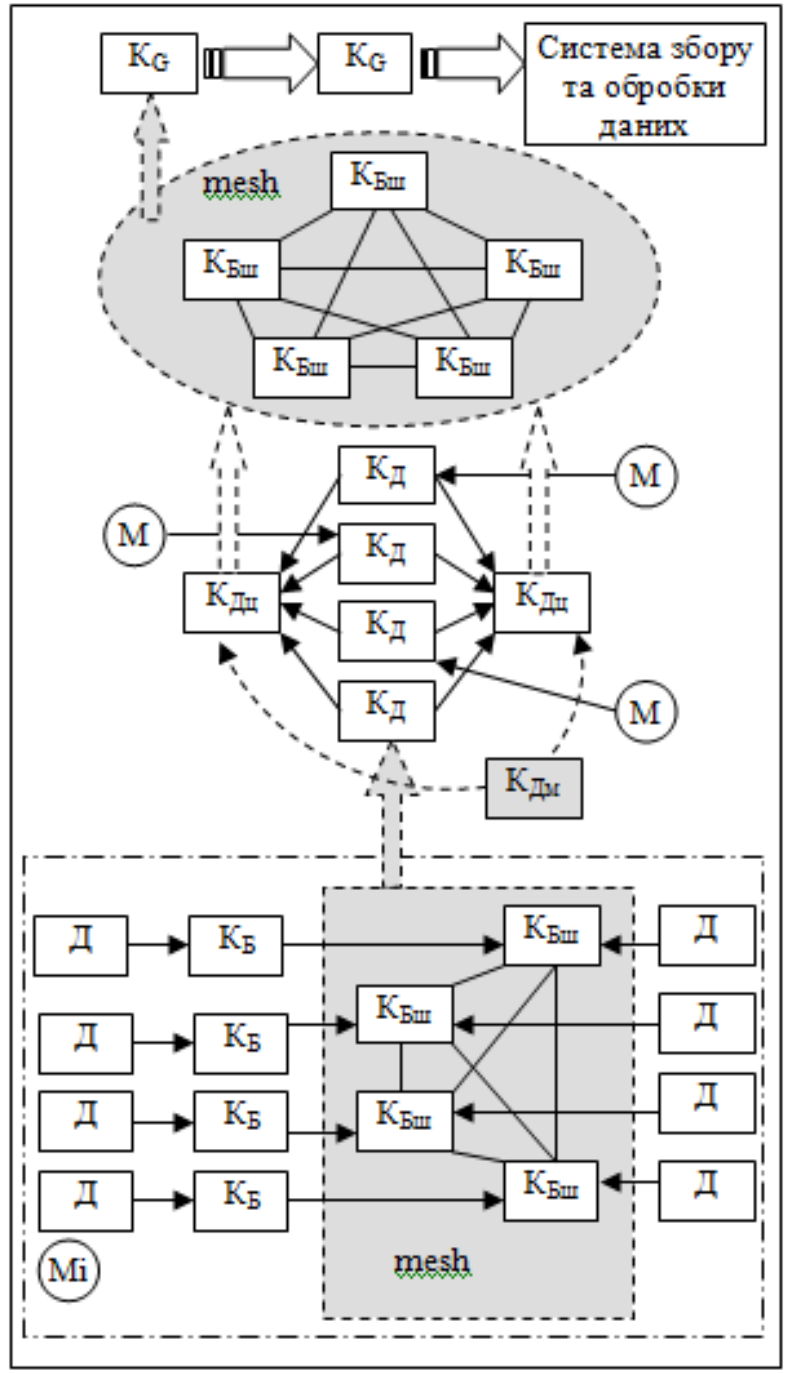

Рис. 3. Модель системи позиціонування

та моніторингу на основі багаторівневої структури їх взаємодії

Джерело: розроблено авторами.

Дана модель має властивості горизонтального та вертикального масштабування. Сутність вертикального масштабування полягає у можливості збільшення вузлів мережі від датчиків до кінцевого вузла передачі даних моніторингу. Збільшення вузлів ме- режі на одному рівні функціональної взаємодії розкриває сутність горизонтального масштабування.

\section{Експериментальне дослідження моделі}

3 метою перевірки можливості реалізації моделі, що запропонована, проведено експериментальне дослідження задачі моніторингу та позиціонування 3 використанням мобільного вузла $\left(K_{\text {Дм }}\right)$. Дослідження проведено на ділянці місцевості зі змінним профілем, що забезпечувало створення ділянок відсутності зв'язку за каналом $K_{\text {д }}$ а також в зонах відсутності покриття стільникового зв’язку (рис. 4-5).

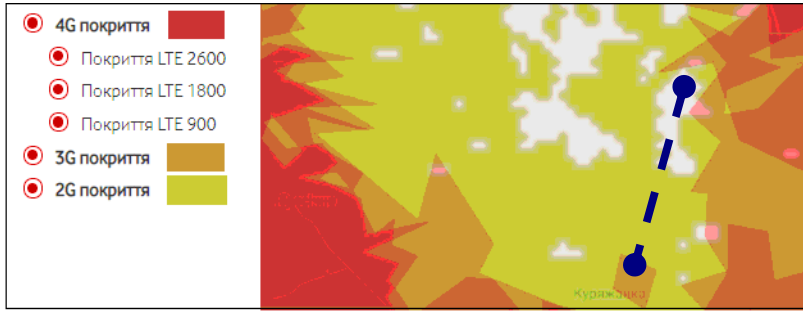

Рис. 4. Район дослідження з використанням зони покриття $2 \mathrm{G}$ та поза нею Джерело: розроблено авторами.

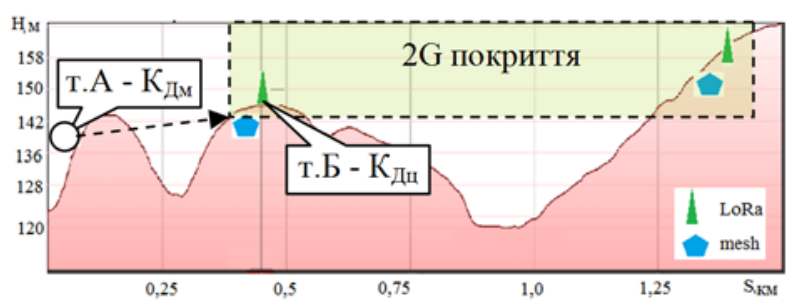

Рис. 5. Схема розташування елементів системи при проведенні дослідження Джерело: розроблено авторами.

В якості інформації, вимірювання та передача якої здійснювалась на сервер, було обрано дані приймачів GPS (U-Blox NEO-6M). Результати позиціонування стаціонарних та рухомого модуля $\left(K_{\text {Дм }}\right)$ наведено на рис. 6 .

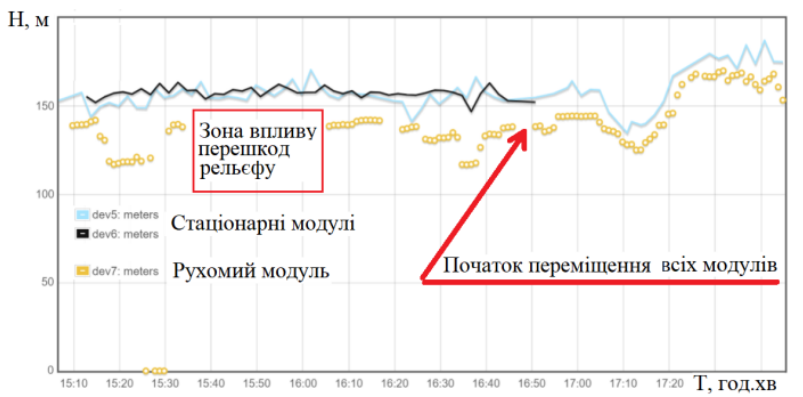

Рис. 6. Параметри висоти модулів за даними GPS (U-Blox NEO-6M).

Джерело: розроблено авторами.

На рисунку видно періоди відсутності даних, які обумовлені впливом перешкод та рельєфу на функціонування каналу обміну даними між вузлами 


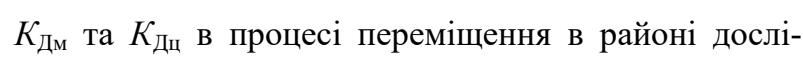
дження. Забезпечення моніторингу в таких зонах (т. А рис. 5) можливе за рахунок додаткового розміщення елементів системи.

За результатами експерименту, щодо дослідження функціонування системи позиціонування та моніторингу на основі запропонованої моделі визначено, що отримані результати відповідають вимогам, які висувались. Дана модель дозволяє створювати локальні та розосереджені зони моніторингу у віддалених районах на основі властивостей автономності. Багаторівнева структура моделі дозволяє формувати індивідуальну топологію для заданого об'єкту, району. Показано, що елементи моделі можуть бути як стаціонарні так і мобільні. Мобільність, як властивість моделі, обумовлює доцільність подальших досліджень в напрямку розгляду рухомих об'єктів, як в якості засобу моніторингу, так і в якості об'єкта, який контролюється. Застосування технології LoRa сумісно з системами стільникового зв'язку дозволяє створювати суцільні зони інформаційного забезпечення.

Наприклад, в гірських районах при виконанні пошуково-рятувальних операцій; на об'єктах, які мають розосереджену структуру, таких як аеродроми, промислові зони та ін.

Таким чином, теоретично обгрунтовано та підтверджено на практиці можливість та доцільність створення системи позиціонування та моніторингу на основі багаторівневої структури взаємодії технологій безпровідної передачі даних.

Вона може бути складовою системи C4ISR при вирішенні задач моніторингу наземної і повітряної обстановки при спільному застосуванні безпілотної та пілотованої авіації.

\section{Висновки}

В роботі показано, що окремі інфокомунікаційні технології мають певні обмеження: за дальністю дії; варіантами топології, які можуть бути реалізовані; можливостями по використанню електронних компонентів в різних додатках М2М та ін. Компенсація таких обмежень можлива за рахунок комплексного застосування різних технологій.

За результатами дослідження визначено, що поєднання розосереджених об'єктів в єдину систему моніторингу можливо реалізувати на основі технологіï LoRa. Моніторинг локальних об'єктів доцільно здійснювати на основі комплексного застосування технологій LoRa та Wi-Fi. Це дозволяє забезпечити функціональну стійкість системи при іiї деградації за рахунок топології Mesh, в якій реалізується функція самоорганізації вузлів мережі. Визначено можливість реалізації топології “подвійна зірка" на основі технологіï LoRa.

Використання інформації за даними GNSS в процесі експерименту підтвердило можливість рішення задачі позиціонування в системі моніторингу. Достовірність отриманих результатів підтверджена використанням даних з відомих джерел геоінформаційних систем. Подальшим напрямком досліджень $€$ визначення можливостей та обмежень при передачі інформаційних потоків. Область застосування моделі, що запропонована, це віддалені райони, де відсутній стільниковий зв'язок, розосереджені промислові об'єкти, аеродроми. Дана модель може бути основою для удосконалення систем пошуково-рятувального забезпечення та системи управління повітряним рухом при застосуванні безпілотних літальних апаратів, в тому числі спільно з пілотованою авіацією.

\section{Список літератури}

1. Гончаренко С. В. Культура безпеки польотів державної авіації України. Наука і оборона. 2019. № 1. С. $36-39$. https://doi.org/10.33099/2618-1614-2019-6-1-36-39.

2. Ситник Ю. Б. Аналіз основних характеристик і показників стану безпеки польотів авіаційної системи. Системи озброєння і військова техніка. 2021. № 2(66). С. 117-22. https://doi.org/10.30748/soivt.2021.66.15.

3. United States Air Force Unmanned Aerial System Flight Plan 2009-2047. Strategy and Policy Papers : web site. URL: https://www.airforcemag.com (accessed: 24.10.2021).

4. Huang-Chen Lee, Kai-Hsiang Ke. Monitoring of Large-Area IoT Sensors Using a LoRa Wireless Mesh Network System: Design and Evaluation. IEEE Transactions on Instrumentation and Measurement. 2018. Vol. 67. No. 9. P. $2177-2167$. https://doi.org/10.1109/TIM.2018.2814082.

5. Ni Ni San Hlaing, Ma Naing, San San Naing. GPS and GSM Based Vehicle tracking system. International Journal of Trend in Scientific Research and Development. 2019. Vol. 2. No. 4. P. 271-275. https://doi.org/10.31142/ijtsrd23718.

6. Якусевич Ю. Г., Тришин В. В., Дорофєєва 3. Я. Побудова навігаційної системи судна на основі сучасних інформаційних технологій. Збірник наукових праџьь Харківського національного університету Повітряних Сил. 2021. № 4(70). C. 83-88. https://doi.org/10.30748/zhups.2021.70.12.

7. Lai W. H., Lai Y. C., Lan Z. S., Lin H. H., Ho W. K. Development of an Internet of Things System Based on Unmanned Aerial Vehicles for the Application of Smart Security from Sky. Journal of Aeronautics, Astronautics and Aviation. 2018. Vol. 50. No. 2. P. 135-146. https://doi.org/10.6125/JoAAA.201806_50(2).03.

8. Петров В. М., Шалигін А. А., Кудрявцев А. Ф., Ситник Ю. Б., Марченко О. М., Сурков К. Ю. Форми та способи спільного застосування пілотованої та безпілотної авіації при веденні бойових дій. Системи озброєння $і$ військова техніка. 2021. № 3(67). C. 31-38. https://doi.org/10.30748/soivt.2021.67.04. 
9. Кірсанов С. О. Методичний підхід до обгрунтування вимог до оперативності роботи органів управління перспективної автоматизованої системи управління військами. Системи озброєння і військова техніка. 2021. № 3(67). C. 81-86. https://doi.org/10.30748/soivt.2021.67.10.

10. Пєвцов Г. В., Олещук М. М. Аналіз спроможностей оглядових РЛС РТВ щодо виявлення, супроводження та ідентифікації безпілотних літальних апаратів. Системи озброєння $і$ військова техніка. 2021. № 3(67). С. 24-30. https://doi.org/10.30748/soivt.2021.67.03.

11. Карташов В., Посошенко В., Воронин В., Колесник В., Капуста А., Рыбников Н., Першин Е. Методы обнаружения-распознавания радиолокационных, акустических, оптических и инфракрасных сигналов беспилотных летательных аппаратов. Радиотехника. 2021. № 2(205). С. 138-153. https://doi.org/10.30837/rt.2021.2.205.15.

12. Карташов В., Харченко О., Посошенко В., Колесник В., Егоров А., Тимошенко Л., Капуста А. Обнаружение беспилотных летательных аппаратов с использованием рассеяния радиоволн на акустических возмущениях среды, создаваемых летательным аппаратом. Радиотехника. 2021. № 3(206). C. 122-130. https://doi.org/10.30837/rt.2021.3.206.11.

13. Сорокін Д. А. Використання технології LoRa для вирішення задачі локалізації об'єктів в IoTсистемах. Електронна та Акустична Інженерія. 2020. № $\quad 3(3)$. С. $34-39 . \quad$ https://doi.org/10.20535/26170965.2020.3.3.198603.

14. Baharudin A. M., Yan W. Long-range wireless sensor networks for geolocation tracking. Design and evaluation : International Electronics Symposium, Denpasar, Indonesia, 29-30 September 2016. Denpasar, 2016. P. 76-80.

15. Istiana T., Mardyansyah R., Dharmawan G. Kajian Pemanfaatan IoT Berbasis LPWAN Untuk Jaringan Akuisisi Data ARG. Elektron : Jurnal Ilmiah. 2020. No.1(12), P. 1-6. https://doi.org/10.30630/eji.12.1.155.

16. Kolobe L., Sigweni B., Lebekwe C. K. Systematic literature survey : Applications of LoRa communications. International Journal of Electrical and Computer Engineering. Vol. 10. No. 3. P. $3176-3183$. https://doi.org/10.11591/ijece.v10i3.pp3176-3183.

17. Барабаш О. В. Построение функционально устойчивых распределенных информационных систем : монография. Киев : НАОУ, 2004. 226 с.

18. Sobchuk A., Kravchenko Y., Tyshchenko M., Gawliczek P., Afanasyeva O. Analytical Aspects of Providing a Feature of the Functional Stability According to the Choice of Technology for Construction of Wireless Sensor Networks. International Conference on Advanced Trends in Information Theory (IEEE ATIT 2019) : conference paper. IEEE, 2019. P. $102-106$. https://doi.org/10.1109/ATIT49449.2019.9030474.

19. Mashkov O. A., Murasov R. K., Kravchenko Y. V., Dakhno N. B., Leschenko O. A., Trush O. V. Optimal forecast algorithm based on compatible linear filtration and extrapolation. Mathematical Modelling and Computing. 2021. Vol. 8. No. 2. P. 157-167. https://doi.org/10.23939/mmc2021.02.157.

20. Карта покриття "Vodafone" в Україні. Vodafone : веб-сайт. URL: http://surl.li/bhvna (дата звернення: 12.12.2021).

21.Afanasiev Yu., Afanasiev V., Chystov V., Sitkov O., Surhai V., Fediuk S. Hierarchical model of a complex of IoT devices based on the use of a wireless sensor network. International Conference on Advanced Trends in Information Theory (IEEE ATIT 2020) : conference paper. IEEE, 2020. P.168-171. https://doi.org/10.1109/ATIT50783.2020.9349340.

\section{Відомості про авторів:}

\section{Тимочко Олександр Іванович} доктор технічних наук професор професор кафедри

Харківського національного університету

Повітряних Сил ім. І. Кожедуба,

Харків, Україна

https://orcid.org/0000-0002-4154-7876

\section{Афанасьсв Володимир Володимирович} кандидат технічних наук доцент докторант

Харківського національного університету

Повітряних Сил ім. І. Кожедуба,

Харків, Україна

https://orcid.org/0000-0003-2978-0023

\section{Афанасьсв Юрій Володимирович} магістрант

Харківського національного університету радіоелектроніки,

Харків, Україна

https://orcid.org/0000-0001-5329-3706

\section{Information about the authors:}

Oleksandr Timochko

Doctor of Engineering Science Professor

Professor of Department

of Ivan Kozhedub Kharkiv

National Air Force University,

Kharkiv, Ukraine

https://orcid.org/0000-0002-4154-7876

\section{Volodymyr Afanasiev}

$\mathrm{PhD}$ in Engineering Associate Professor

Doctoral Candidate

of Ivan Kozhedub Kharkiv

National Air Force University, Kharkiv,

Ukraine

https://orcid.org/0000-0003-2978-0023

\author{
Yuriy Afanasiev \\ Undergraduate \\ of Kharkiv National University \\ of Radio Electronics, \\ Kharkiv, Ukraine \\ https://orcid.org/0000-0001-5329-3706
}




\author{
Аросланкін Олександр Олегович \\ ад'юнкт \\ Харківського національного університету \\ Повітряних Сил ім. І. Кожедуба, \\ Харків, Україна \\ https://orcid.org/0000-0001-6364-6368
}

\author{
Oleksandr Aroslankin \\ Post-Graduate \\ of Ivan Kozhedub Kharkiv \\ National Air Force University, \\ Kharkiv, Ukraine \\ https://orcid.org/0000-0001-6364-6368
}

\title{
МОДЕЛЬ СИСТЕМЫ ПОЗИЦИОНИРОВАНИЯ И МОНИТОРИНГА НА ОСНОВЕ МНОГОУРОВНЕВОЙ СТРУКТУРЫ ПЕРЕДАЧИ ДАННЫХ В РАСПРЕДЕЛЕННОЙ СЕТИ
}

\author{
А.И. Тимочко, В.В. Афанасьев, Ю.В. Афанасьев, А.О. Аросланкин
}

Эффективное и безопасное выполнение задач авиацией зависит от качества организации управления воздушным движением, контроля за движением наземных средств, состояния функционирования наземных средств обеспечения полетов, мониторинга метеорологической и орнитологической обстановки. Одним из путей обеспечения выполнения этих задач является создание единого информационного пространства, базирующегося на принципах реализации конuепции C4ISR. К ее основным компонентам относятся беспроводные технологии связи, спутниковые радионавигационные системы, на основе которых осуществляется мониторинг обстановки, управление функциональными структурами системы. Каждая отдельная составляющая имеет ограничения, которые могут быть скомпенсированы за счет комплексного применения различных инфокоммуникационных технологий. В работе предложена модель системы позиционирования и мониторинга на основе многоуровневой структуры передачи данных в распределенной сети. Обоснование модели выполнено на основе исследования технологий обмена данными, аппаратных компонентов, программного обеспечения, вариантов топологии построения систем обмена данными. Проведено экспериментальное исследование реализации функций мониторинга и позиционирования на основе применения предлагаемой модели. Показано, что к основным свойствам модели относятся: масштабирование структуры в зависимости от конкретных задач, возможность комплексного применения стационарных и подвижных элементов, осуществляющих сбор, обработку и передачу данных. По результатам исследования определено, что сочетание рассредоточенных объектов в единую систему мониторинга можсн реализовать на основе технологии LoRa. Мониторинг локальных объектов иелесообразно производить на основе комплексного применения технологий LoRa u Wi-Fi. Это позволяет обеспечить функциональную устойчивость системы при ее деградации за счет топологии Mеsh, в которой реализуется функция самоорганизации узлов сети. Область применения предлагаемой модели, это отдаленные районы, где отсутствует сотовая связь, рассредоточены промышленные объекты, аэродромы. Данная модель может являться основой для усовершенствования систем поисково-спасательного обеспечения и системы управления воздуиным движением при применении беспилотных летательных аппаратов, в том числе совместно с пилотируемой авиацией.

Ключевые слова: беспилотные летательные аппараты, модель, мониторинг, система навигачии, позиционированuе, LoRa, Wi-Fi.

\section{A MODEL OF A POSITIONING AND MONITORING SYSTEM BASED ON A MULTI-LEVEL STRUCTURE OF DATA TRANSMISSION IN A DISTRIBUTED NETWORK}

O. Timochko, V. Afanasiev, Yu. Afanasiev, O. Aroslankin

Efficient and safe performance of tasks by aviation depends on the quality of air traffic control organization, control over the movement of ground vehicles, the state of operation of ground-based flight support facilities and monitoring of meteorological and ornithological conditions. One of the ways to ensure the fulfillment of these tasks is to create a unified information space based on the principles of the implementation of the C4ISR concept. Its main components include wireless communication technologies, satellite radio navigation systems, based on which the situation is monitored, and the functional structures of the system are controlled. Each individual component has limitations that can be compensated for through the complex use of various infocommunication technologies. The article proposes a model of a positioning and monitoring system based on a multi-level structure of data transmission in a distributed network. The model is substantiated based on a study of data exchange technologies, hardware components, software, topology options for building data exchange systems. An experimental study of the implementation of monitoring and positioning functions was carried out based on the application of the proposed model. It is shown that the main properties of the model include scaling the structure depending on specific tasks, the possibility of complex application of stationary and moving elements that collect, process, and transmit data. According to the results of the study, it was determined that the unification of disparate objects into a single monitoring system can be implemented based on LoRa technology. It is desirable to manage local facilities based on the integration of LoRa and Wi-Fi technologies. This makes it possible to ensure the functional stability of the system during its degradation due to the Mesh topology, which implements the function of self-organization of network nodes. The scope of the proposed model is in remote areas where there is no cellular communication, industrial facilities and airfields are scattered. This model can be the basis for improving search and rescue systems and air traffic control when using unmanned aerial vehicles, including in conjunction with manned aircraft.

Keywords: unmanned aerial vehicles, model, monitoring, navigation system, positioning, LoRa, Wi-Fi. 